\title{
CZY DZIECKU PRZYSŁUGUJE PRAWO DO USTALENIA POCHODZENIA GENETYCZNEGO ZE STRONY MATKI?
}

\begin{abstract}
Streszczenie. W tekście zajęto się problematyką dotyczącą prawa dziecka do określenia jego pochodzenia genetycznego w zakresie ustalenia macierzyństwa, również w odniesieniu do problemu technik medycznie wspomaganej prokreacji oraz tzw. macierzyństwa zastępczego. Podjęcie niniejszej tematyki stanowi odpowiedź na pytania stawiane wobec coraz szybciej rozwijającej się nauki i medycyny. Artykuł jest także próbą zestawienia przepisów prawa z poglądami przedstawicieli doktryny oraz z codzienną praktyką w odniesieniu do prawa do ustalenia pochodzenia.

Słowa kluczowe: prawo dziecka do informacji o pochodzeniu genetycznym, dziecko, macierzyństwo, macierzyństwo zastępcze, medycznie wspomagana prokreacja.
\end{abstract}

\section{WSTĘP}

Szeroko rozumiane prawo dziecka do znajomości własnego pochodzenia w dobie wciąż rozwijających się technik prokreacji medycznie wspomaganej stanowi niezwykle istotne zagadnienie na gruncie etycznym, biologicznym i prawnym. Jego wielowymiarowość zdecydowanie wymaga dokonania analizy prawnych możliwości poznania własnej tożsamości przez dziecko.

Wyjątkowa, indywidualna historia każdego człowieka bierze swój początek w momencie połączenia się komórek rozrodczych jego rodziców. Współczesny stan wiedzy daje możliwość poczęcia i urodzenia dziecka w sposób zupełnie nowatorski, czasami bez konieczności obcowania płciowego, co jeszcze jakiś czas temu wydawałoby się całkowicie nieprawdopodobne. W świecie, w którym rzymska paremia mater semper certa est traci swoje znaczenie, jednym $\mathrm{z}$ istotnych problemów stało się zagadnienie prawa dziecka do poznania swego pochodzenia.

Nie można pominąć kwestii dotyczących prawa dziecka do znajomości swego pochodzenia, które przed nowelizacją Kodeksu rodzinnego i opiekuńczego z 6 listopada 2008 r. (Dz.U. z 2017 r., poz. 682) nie miały kompleksowych rozwiązań, w szczególności w odniesieniu do coraz to częściej występującego procederu tzw. macierzyństwa zastępczego. Ustawodawca polski stanął na stanowisku, zgodnie

* Uniwersytet Śląski, Wydział Prawa i Administracji, Katedra Prawa Cywilnego i Prawa Prywatnego Międzynarodowego, magdalenasobas@interia.pl. 
z którym w sprawach dotyczących tak delikatnej i subtelnej materii, jaką jest ustalenie pochodzenia dziecka, w momencie gdy pojawiają się ludzkie uczucia, emocje czy tradycyjne odruchy rodzicielskie należy mimo wszystko przyjąć rzymską zasadę dura lex, sed lex.

Niewątpliwie istotnym zagadnieniem w odniesieniu do prawa dziecka do poznania swego pochodzenia jest również możliwość zastosowania wspomnianych już zabiegów medycznie wspomaganej ludzkiej prokreacji, takich jak inseminacja homologiczna czy heterologiczna i technika zapłodnienia in vitro.

Podjęcie niniejszej tematyki stanowi odpowiedź na pytania stawiane wobec coraz szybciej rozwijającej się nauki i możliwości, jakie w dzisiejszym świecie daje człowiekowi medycyna i dziedziny pokrewne, w konfrontacji z zagwarantowanym dziecku prawem do poznania swego pochodzenia. Tekst ten stanowi zarówno próbę zestawienia przepisów prawa z poglądami przedstawicieli doktryny, jak i z praktyką.

\section{POCZĄTKI PRAWA DO ZNAJOMOŚCI WLASNEGO POCHODZENIA W USTAWODAWSTWIE ŚWIATOWYM}

Pierwszym europejskim aktem prawnym, w którym problem ten został unormowany, była szwedzka ustawa o inseminacji z 20 grudnia 1984 r., zgodnie z którą dziecko urodzone w wyniku takiego zabiegu, przeprowadzonego z uwzględnieniem wymagań w niej określonych, miało prawo po osiągnięciu wystarczającej dojrzałości do osobistego wglądu do danych dotyczących dawcy nasienia.

Na gruncie prawa zachodnioniemieckiego prawo dziecka do poznania własnego pochodzenia genetycznego wywodziło się z Konstytucji RFN. Konstytucja ta przesądzała, że nie istnieje jakakolwiek możliwość zachowania anonimowości dawcy nasienia w przypadku inseminacji heterologicznej. Podkreślano, że znajomość własnego pochodzenia jest wartością o niezwykłej wadze zarówno w zakresie samoidentyfikacji, jak i rozwoju własnej osobowości (Zielonacki 1993, 102). $Z$ kolei zachowanie anonimowości byłoby niezgodne $\mathrm{z}$ konstytucją $\mathrm{w}$ świetle prawa do godności ludzkiej (Zielonacki 1993, 103).

W Stanach Zjednoczonych Ameryki Północnej w 1973 przyjęto Uniform Parentage Act. Ustawa ta przewidywała znaczną anonimowość dawcy komórek rozrodczych, jednak została ona ograniczona poprzez regulacje dotyczące obowiązku udostępnienia wszystkich dokumentów i danych o inseminacji w przypadku, gdy sąd tak zarządzi. W USA, jako jedną z przesłanek udostępnienia danych na skutek zarządzenia sądu, akcentowało się interes dziecka w poznaniu swej tożsamości genetycznej poprzez ujawnienie danych rodziców (Stecki, Winiarz, Gajda 1990, 69).

W różnych krajach źródeł prawa dziecka do poznania swego pochodzenia genetycznego poszukiwało się w kodeksach cywilnych, które nierzadko 
przewidywały uprawnienie do zapoznania się z dokumentami dotyczącymi pochodzenia osoby ludzkiej (Stecki, Winiarz, Gajda 1990, 72), w konstytucji, przewidującej chociażby prawo do godności, czy w innych aktach prawnych.

\subsection{Prawo dziecka do informacji o pochodzeniu genetycznym w prawie międzynarodowym}

Termin „dziecko” jest wieloznaczny. Intuicyjnie oznacza okres, w którym mały człowiek nie jest dojrzały zarówno fizycznie, jak i psychicznie (Smyczyński 1999, 39).

Fundamentalne prawa dziecka zawarto w Powszechnej Deklaracji Praw Człowieka przyjętej przez Zgromadzenie Ogólne Organizacji Narodów Zjednoczonych dnia 10 grudnia 1948 r., a następnie w Europejskiej Konwencji o Ochronie Praw Człowieka i Podstawowych Wolności sporządzonej w Rzymie dnia 4 listopada 1950 r. Kolejnym, międzynarodowym dokumentem regulującym prawa dzieci była Deklaracja Praw Dziecka uchwalona przez Zgromadzenie Ogólne Organizacji Narodów Zjednoczonych dnia 20 listopada 1959 r., która w sposób zdecydowany poszerzała katalog praw dzieci, a jej wstęp wskazywał m.in. na obowiązek ludzkości zapewnienia dzieciom tego, co ma dla nich najlepszego (Wiśniewski 1999, 12). Powstanie Deklaracji Praw Dziecka było niezwykle ważnym impulsem do zainicjowania prac nad przygotowaniem Konwencji o Prawach Dziecka, przyjętej przez Zgromadzenie Ogólne Narodów Zjednoczonych 20 listopada 1989 r., a w szczególności art. 7, gwarantującego każdemu dziecku prawo do poznania jego biologicznych rodziców (Wiśniewski 1999, 12).

Najważniejsze w treści art. 7 Konwencji o Prawach Dziecka, w kontekście powyższych rozważań, jest zapewnienie dziecku prawa (o ile to możliwe) do poznania swoich rodziców i pozostawania pod ich opieką. Prawo to należy rozumieć dwojako. $Z$ jednej strony jest to prawo do poznania pochodzenia biologicznego, czyli ustalenia, kto jest biologicznym ojcem, a kto biologiczną matką, a drugiej strony jest to prawo do nawiązania $\mathrm{z}$ rodzicami więzi emocjonalnej. Zawarty $\mathrm{w}$ art. 7 zwrot „o ile jest to możliwe” niewątpliwie osłabia prawo dziecka do poznania rodziców i pozostawania pod ich opieką (Działyńska 1999, 135).

Zgodnie z przedstawioną analizą państwo, które ratyfikuje Konwencję o Prawach Dziecka, spełnia obowiązek nałożony na nie w art. 7 dopiero wówczas, gdy jego system prawny stwarza faktyczną, realną możliwość ustalenia przez dziecko swojego biologicznego pochodzenia i poznania biologicznych rodziców. Państwo nie musi dawać gwarancji, że zawsze, w każdym przypadku, w każdej sytuacji dziecko będzie w stanie ustalić swoje pochodzenie, jednakże jedynymi przeszkodami, które mogą ograniczać bądź wyłączać tę możliwość są przeszkody obiektywne. Można tutaj wskazać chociażby sytuację, w której dziecko zostaje porzucone przez matkę, czy to poprzez pozostawienie go w tzw. oknie życia, czy też poprzez porzucenie w jakimkolwiek innym miejscu, a tożsamości matki, mimo usilnych starań, nie udało się ustalić, co jest również następstwem niemożności ustalenia tożsamości dziecka ze strony ojca (Działyńska 1999, 135). 


\subsection{Prawo dziecka do poznania swego pochodzenia w prawie polskim}

Dokonując analizy polskiego systemu prawnego, należy stwierdzić, że najważniejszym aktem prawnym, odnoszącym się do kwestii szeroko rozumianych praw dziecka (Jaros 2003, 35), jest ustawa z dnia 2 kwietnia 1997 r. Konstytucja Rzeczypospolitej Polskiej (Dz.U. z 1997 r. Nr 78, poz. 483), która w rozdziale II zawiera postanowienia stanowiące niezwykle istotną wskazówkę dotyczącą sposobu traktowania dzieci we wszelkich aspektach ich życia.

Istotnym aktem $\mathrm{w}$ polskim porządku prawnym dotyczącym praw dziecka w zakresie aktów stanu cywilnego jest ustawa z dnia 29 września 1986 r. - Prawo o aktach stanu cywilnego (Dz.U. z 2016 r., poz. 2064; dalej: p.a.s.c.), która wskazuje między innymi na obowiązek zagwarantowania dziecku w każdej sytuacji prawa do imienia i nazwiska - art. 50 p.a.s.c. (Czyż, Szymańczak 1993, 5).

Podstawowym krajowym aktem prawnym regulującym materię dotyczącą dzieci jest ustawa z dnia 25 lutego 1964 r. - Kodeks rodzinny i opiekuńczy (Dz.U. z 2015 r., poz. 2082; dalej: k.r.o.), która zawiera kompleksowe rozwiązania dotyczące prawa dziecka do poznania swego pochodzenia. Kodeks rodzinny i opiekuńczy wyposaża dziecko nie tylko w legitymację czynną do wszczęcia postępowania w przedmiocie ustalenia macierzyństwa (art. $61^{10} \S 2$ k.r.o.) czy jego zaprzeczenia (art. $61^{12} \S 2$ k.r.o.), ale również ustalenia ojcostwa (art. 84 k.r.o.) lub zaprzeczenia ojcostwa (art. 70 k.r.o.). Ponadto wprowadza kompleksową ochronę chociażby ze względu na fundamentalną zasadę prawa rodzinnego, jaką jest dobro dziecka.

\section{KWESTIA MACIERZYŃSTWA ZASTĘPCZEGO}

W dzisiejszym świecie stale wzrasta liczba par, które nie mogą posiadać własnego, genetycznego potomstwa, co prowadzi do sytuacji, w której niepłodność jednego lub obojga partnerów skłania ich do poszukiwania alternatywnych możliwości posiadania dziecka (Wałachowska 2009, 97). W takim przypadku para, która w sposób naturalny nie może począć dziecka, ma możliwość wyboru pomiędzy leczeniem niepłodności, adopcją bądź nową techniką urodzenia dziecka, jaką jest tzw. macierzyństwo zastępcze.

Obecnie rozwój medycyny, biotechnologii oraz genetyki sprawił, że lekarze coraz częściej są w stanie skutecznie przeprowadzać zabiegi polegające na zapłodnieniu ludzkich komórek rozrodczych poza organizmem kobiety (Działyńska 1993, 87). Macierzyństwo zastępcze jest możliwe dzięki połączeniu techniki sztucznej inseminacji i zapłodnienia in vitro, które w literaturze prawniczej nazywane są technikami wspomaganej ludzkiej prokreacji (Silva-Ruiz 1991, 123). Potocznie mianem macierzyństwa zastępczego określa się sytuację, w której kobieta decyduje się pełnić rolę matki wobec dziecka urodzonego przez inną kobietę (Działyńska 
1996, 113). Powoduje to, że z praktycznego punktu widzenia macierzyństwo zastępcze jest korelatem instytucji opieki, którą powinna sprawować osoba związana $\mathrm{z}$ dzieckiem względami pokrewieństwa. W istocie kobieta, która podejmuje decyzję o pełnieniu roli matki, zastępuje dziecku matkę genetyczną w odniesieniu do wszelkich obowiązków względem dziecka (Działyńska 1993, 88).

Istotą instytucji macierzyństwa zastępczego jest decyzja podejmowana przez kobietę o zajściu w ciążę, urodzeniu dziecka, oddaniu dziecka innej parze (bądź osobie) oraz przeniesieniu na tę parę (bądź osobę) praw rodzicielskich (Holocher, Soniewicka 2009, 43). W związku z coraz szybszym rozwojem nauki, techniki, a także wzrostem tempa życia społeczeństwa, w szczególności w krajach wysoko uprzemysłowionych, coraz częściej spotykamy się z tą instytucją. Materią wywołującą najwięcej sporów i wątpliwości jest dopuszczalność umów, których przedmiotem jest macierzyństwo zastępcze, ich treść, kwestia odpłatności, jednak problematyka ta jest odrębnym przedmiotem rozważań (Wałachowska 2003, 97), a także kwestia ustalenia pochodzenia dziecka oraz jego prawo do informacji o własnym pochodzeniu.

\subsection{Odpowiedzialność prokreacyjna a macierzyństwo zastępcze}

W świetle omówionej możliwości implantacji do organizmu kobiety embrionu, powstałego wskutek pozaustrojowego zapłodnienia komórki jajowej pochodzącej od innej kobiety (Fras, Abłażewicz 2008, 32), fundamentalnym problemem prawnym, który wiąże się z zagadnieniem macierzyństwa zastępczego staje się kwestia ustalenia pochodzenia dziecka, w szczególności ze strony matki (Żukowski 2013, 310). Instytucja macierzyństwa zastępczego jest źródłem wielu dylematów dotyczących sytuacji prawnej matki zastępczej oraz matki genetycznej. W tej sytuacji łacińska paremia mater semper certa est traci swoje znaczenie, w związku z czym nasuwa się pytanie, którą z kobiet należy uznać za matkę dziecka - tę, która jest dawcą komórki jajowej, czy tę, która dziecko urodziła (Fras, Abłażewicz 2008, 32).

Kwestią podstawową staje się sposób rozumienia rodzicielstwa bądź macierzyństwa, a także powiązanych z nimi praw i obowiązków (Soniewicka, 2009, 8). Jak wskazuje Marta Soniewicka, rozstrzygając kwestię macierzyństwa, należałoby wziąć pod uwagę kilka wymiarów formowania się relacji rodzicielskiej pomiędzy matką a dzieckiem. Na najwcześniejszym etapie należy wskazać na sam fakt przekazania komórki jajowej (więź genetyczna), następnie tworzenie relacji podczas ciąży (więź biologiczna), aż w końcu samo zapoczątkowanie procesu związanego z przyjściem dziecka na świat (więź społeczna, prawna z dzieckiem, które urodziło się w wyniku podjęcia starań w zakresie przeprowadzenia zapłodnienia pozaustrojowego innej kobiety) (Soniewicka 2009, 8-9).

$\mathrm{W}$ ten sposób dziecko, które przychodzi na świat, jest nie tylko związane z kobietą, która je urodziła, ale również z kobietą, od której pochodzi komórka rozrodcza (Działyńska 1993, 93). 
Prokreacja to proces, któremu należy przyjrzeć się nie tylko z punktu widzenia biologii czy medycyny, ale również etyki oraz prawa, które tworzą podstawę dla rozumienia pojęcia macierzyństwa czy rodzicielstwa. Istnieje możliwość przyjęcia, że kluczową wartością prokreacji jest autonomia korzystania z wszelkich dostępnych metod reprodukcyjnych, jednakże nie jest to jedyna wartość prokreacji, jaką możemy uznać (Soniewicka 2009, 9).

Macierzyństwo zastępcze jako jedna z metod zaliczonych w 2009 roku przez Światową Organizację Zdrowia (WHO) do technik wspomaganej prokreacji (Żukowski 2013, 309) stanowi reakcję na potrzebę posiadania dziecka, które jednocześnie może być spokrewnione z osobami niemogącymi w sposób naturalny wydać na świat potomstwa (Soniewicka 2009, 10). W każdym przypadku należy zastanowić się nad relacją rodzicielstwa ściśle związaną z pojęciem odpowiedzialności prokreacyjnej. Niezwykle istotną kwestię stanowi zagadnienie biologicznej, a nawet etycznej odpowiedzialności za sam proces prokreacji, co znajduje wyraz w prawach i obowiązkach osób, które zawarły umowę, porozumienie odnoszące się do wydania dziecka na świat. Ze względu na trudności z przypisaniem odpowiedzialności istnieje potrzeba separacji procesu prokreacji od odpowiedzialności rodzicielskiej (Soniewicka 2009, 11). W każdym przypadku jednak należy kierować się dobrem dziecka, a także gwarantowaną mu przez prawo możliwością poznania własnego pochodzenia, swojej tożsamości genetycznej.

\subsection{Prawo dziecka do informacji o pochodzeniu genetycznym oraz szczególna postać tajemnicy lekarskiej w przypadku wspomaganego medycznie rozrodu w świetle macierzyństwa zastępczego}

Pośród zagadnień dotyczących macierzyństwa zastępczego na szczególną uwagę zasługuje interes dziecka. Konfrontując interes dziecka z interesem kobiety, która dziecko urodziła i tej, która była dawcą komórki rozrodczej, osobisty interes każdej z nich schodzi na dalszy plan (Działyńska 1993, 97). Ustawodawca przed nowelizacją Kodeksu rodzinnego i opiekuńczego z 2008 r. nie rozstrzygał problemu dotyczącego ustalenia pochodzenia dziecka od matki (Kramska 2010). Kwestia dotycząca ustalenia, która $\mathrm{z}$ kobiet powinna być uznana za matkę w prawnym rozumieniu, a co za tym idzie wpisana również do aktu urodzenia dziecka, rozstrzygana była w kontekście przepisów ustawy Prawo o aktach stanu cywilnego (Kramska 2010). Zgodnie z art. 39 ustawy p.a.s.c. „Do zgłoszenia urodzenia dziecka obowiązani są ojciec dziecka albo matka, jeżeli stan zdrowia na to pozwala, albo inna osoba obecna przy porodzie", co było podstawą przyjęcia, iż decydujące znaczenie dla aktu urodzenia ma akt porodu, a nie genetyczne powiązanie (Kramska 2010). Nowelizacja Kodeksu rodzinnego i opiekuńczego w art. $61^{9}$ kwestię tę w sposób zdecydowany rozstrzygnęła na korzyść kobiety, która dziecko wydała na świat. Zmiana ta miała na celu rozwiązanie sporów, jakie pojawiały się pomiędzy tą, która urodziła, a kobietą, która była 
dawcą komórki rozrodczej, w sytuacji, gdy doszło do zastosowania instytucji macierzyństwa zastępczego (Kramska 2010). Mimo tak jasno określonego przez ustawodawcę stanowiska wprowadzono możliwość wystąpienia z powództwem o ustalenie lub zaprzeczenie macierzyństwa, które niewątpliwie jest wyrazem prawa dziecka do poznania swego pochodzenia. Kwestie odnoszące się do niejednokrotnie niezwykle skomplikowanych relacji, jakie łączą matkę zastępczą z osobami, które dzięki jej udziałowi w procesie prokreacji uzyskały dziecko, zostały rozstrzygnięte (Kramska 2010). Jak zauważa Mirosław Nesterowicz, umowa zawarta z matką zastępczą jest sprzeczna z zasadami współżycia społecznego, o których mowa w art. $58 \S 2$ k.c., a co za tym idzie - powoduje nieważność takiej umowy (Nesterowicz 2007, 258). Współcześnie sądy coraz częściej zmuszone są rozstrzygać sprawy dotyczące ustalenia pochodzenia dziecka, które przyszło na świat dzięki instytucji macierzyństwa zastępczego, w których z jednej strony występuje matka zastępcza, a z drugiej tzw. rodzice społeczni (Kramska 2010).

W przypadku zabiegów wykorzystujących metody sztucznej prokreacji sprawę dodatkowo komplikuje kwestia tajemnicy lekarskiej. Żadnych wątpliwości nie budzi jednak fakt, że lekarz który przeprowadza czynności związane z medycznie wspomaganą ludzką prokreacją powinien stosować ogólne zasady postępowania $w$ tego typu zabiegach oraz powinien zwracać niezwykłą uwagę na postanowienia ustawy z dnia 5 grudnia 1996 r. o zawodach lekarza i lekarza dentysty (Dz.U. z 2018 r., poz. 617), Kodeksu Etyki Lekarskiej, a także regulacje zawarte w Stanowisku Polskiego Towarzystwa Ginekologicznego (PTG), dotyczącym technik wspomaganego rozrodu w leczeniu niepłodności (Haberko, Kocyłowski 2006, 18-19). Co do zasady tajemnica lekarska nie obowiązuje lekarza oraz personel medyczny jedynie w stosunku do samego pacjenta (Haberko, Kocyłowski 2006, 19). Problematyka tajemnicy lekarskiej odnoszącej się do zabiegów medycznie wspomaganej ludzkiej prokreacji oraz poufnych rejestrów gromadzących informacje na temat przeprowadzanych zabiegów sztucznego zapłodnienia jest ściśle związana z prawem dziecka do poznania swego genetycznego pochodzenia oraz ujawnienia danych na temat jego pochodzenia (Rejman 1996, 22). Problem staje się niezwykle istotny, gdy dziecko osiąga pełnoletniość i dąży do poznania pochodzenia genetycznego poprzez uzyskanie informacji dotyczących biologicznego ojca (dawcy nasienia) bądź biologicznej matki, jeżeli przyszło na świat przy pomocy matki zastępczej (Nesterowicz 2008).

W Polsce zagadnienie prawa dziecka poczętego w wyniku technik wspomaganej ludzkiej prokreacji do poznania pochodzenia genetycznego wywołuje wiele kontrowersji i jest niezwykle skomplikowane, szczególnie w odniesieniu do braku dokładnych, wyczerpujących regulacji prawnych, które normowałyby ten problem, a które zderzają się z obowiązkiem zachowania tajemnicy lekarskiej. Podstawowym problemem dotyczącym tej kwestii jest ustalenie, czy istnieje możliwość niedopuszczenia ze względu na regulacje związane $\mathrm{z}$ tajemnicą zawodową i służbową lekarza oraz personelu medycznego do ujawnienia danych, dzięki którym poznanie pochodzenia 
genetycznego przez dziecko stałoby się mniej skomplikowane. Nie istnieją żadne podstawy do uznania wyższości prawa do zachowania anonimowości przez dawcę gamet nad prawem do poznania tożsamości biologicznej (Rejman 1996, 22).

\section{USTALENIE POCHODZENIA DZIECKA W ŚWIETLE ARTYKULU 619 I NASTĘPNYCH KODEKSU RODZINNEGO I OPIEKUŃCZEGO}

W zdecydowanej większości przypadków ustalenie, kto jest matką dziecka nie budzi jakichkolwiek wątpliwości. Uruchomienie procedury mającej na celu ustalenie macierzyństwa jest niezbędne w wyjątkowych przypadkach, które z reguły dotyczą sytuacji, kiedy wcześniej porzucone dziecko zostaje odnalezione lub gdy dochodzi do „zamiany” nowonarodzonych dzieci w szpitalu (Andrzejewski 2011, 123). Współcześnie jednak coraz częściej ustalenie macierzyństwa dokonywane jest w odniesieniu do sztucznie wspieranej ludzkiej prokreacji, co sprowadza się do ustalenia, czy matką dziecka jest kobieta, która dziecko urodziła, czy też kobieta, która oddała swoją zapłodnioną in vitro komórkę jajową (Andrzejewski 2011, 124).

W doktrynie od wielu lat wskazywano na konieczność wprowadzenia do Kodeksu rodzinnego i opiekuńczego przepisów, które będą odnosić się do problematyki ustalenia macierzyństwa (Ignatowicz, Nazar 2005, 229). Jedyną wskazówkę odnoszącą się do ustalenia pochodzenia dziecka zawierał art. 86 k.r.o., w którym zapisano zwrot ",powództwo o ustalenie pochodzenia dziecka”, na które to pochodzenie składa się również ustalenie pochodzenia dziecka od matki (Smyczyński 2009, 173). Z kolei źródła powództwa o ustalenie macierzyństwa poszukiwano w przepisach ustawy z dnia 17 listopada 1964 r. - Kodeks postępowania cywilnego (Dz.U. z 2018 r., poz. 1360; dalej: k.p.c.), w szczególności w art. 189 k.p.c. oraz unormowań k.p.c., odnoszących się do postępowania odrębnego w sprawach ze stosunków między rodzicami a dziećmi. Problem ustalenia macierzyństwa, a co za tym idzie genetycznego pochodzenia dziecka, stał się szczególnie istotny w następstwie rozwoju nauki - medycyny, biotechnologii, biologii czy techniki medycznej (Stojanowska, Kosek 2011, 100), a także zjawiska tzw. macierzyństwa zastępczego. Postęp sprawił, że zaistniała potrzeba dysocjacji pojęcia macierzyństwa genetycznego, które polega na tym, że dziecko pochodzi genetycznie od innej kobiety niż ta, która je urodziła, oraz macierzyństwa biologicznego, które polega na fakcie urodzenia dziecka przez określoną kobietę (Kosek 2011, 100).

Obecnie podstawowym unormowaniem w zakresie ustalenia macierzyństwa jest przepis art. $61^{9}$ k.r.o., zgodnie z którym „matką dziecka jest kobieta, która je urodziła" (Kosek 2011, 98). Ustawodawca opowiedział się niejako po stronie przedstawicieli doktryny, którzy w zdecydowanej większości wskazywali na konieczność uregulowania problemu dotyczącego macierzyństwa, zgodnie z rzymską paremią mater semper certa est, na rzecz prawnego macierzyństwa tej kobiety, która dziecko urodziła (Gołowkin-Hudała 2007, 78). 
Przed nowelizacją z 2008 r. Kodeks rodzinny i opiekuńczy nie regulował ani przesłanek ustalenia i zaprzeczenia macierzyństwa, ani legitymacji procesowej w sprawach dotyczących tych kwestii, co uzasadniane było pewnością stosunku prawno-rodzinnego, jaki występuje pomiędzy matką i dzieckiem, opartego na fakcie urodzenia (Gołowkin-Hudała 2007, 162). W tym zakresie można wyróżnić następujące dwie instytucje prawne - zawartą $\mathrm{w}$ art. $61^{10}$ k.r.o. możliwość ustalenia macierzyństwa oraz wynikającą z art. $61^{12}$ k.r.o. możliwość zaprzeczenia macierzyństwa. Te szczegółowe regulacje przyznają między innymi dziecku prawo do wytoczenia powództwa, co niewątpliwie jest przejawem realizacji prawa dziecka do poznania swego biologicznego, genetycznego pochodzenia.

Zarówno w przypadku powództwa o ustalenie macierzyństwa, jak i powództwa o jego zaprzeczenie doniosłą rolę pełnią dowody mające na celu wykazanie pochodzenia dziecka od określonej osoby. Należy wówczas przeprowadzić dowód ułatwiający ustalenie faktu porodu oraz identyczności dziecka urodzonego w trakcie tego porodu. W razie wątpliwości istnieje możliwość zastosowania dalszych ekspertyz, w tym ekspertyzy serologicznej czy antropologicznej oraz badania DNA (Gołowkin-Hudała 2007, 80).

Ustalenie pochodzenia dziecka od konkretnej kobiety jest faktem mającym elementarne znaczenie. W postępowaniach tych niezwykle ważnym dobrem, wymagającym ochrony i poszanowania, są powiązania, jakie występują pomiędzy osobami, które od wielu lat funkcjonują jako rodzina, mimo że nie są ze sobą spokrewnione. Drugą wartością jest ustalenie stanu cywilnego dziecka, co bezpośrednio wiąże się z jego prawem do informacji o własnym pochodzeniu (Gołowkin-Hudała 2007, 85). Problem ten można sprowadzić do pytania: czy sąd przy rozstrzyganiu spraw o ustalenie lub zaprzeczenie macierzyństwa powinien kierować się zasadami współżycia społecznego, czy też powinien oprzeć rozstrzygnięcie na zasadzie prawdy obiektywnej. Na tle tego zagadnienia powstały rozbieżności w doktrynie i orzecznictwie.

Sąd Najwyższy w uchwale z 7 czerwca 1971 r. (III CZP 87/70; OSNCP 1972, nr 3, poz. 42), stwierdził, że

Zasady współżycia społecznego [...] mogą stanowić podstawę do oddalenia powództwa o zaprzeczenie macierzyństwa tylko wyjątkowo. Może to w szczególności nastąpić wówczas, gdy macierzyństwu stwierdzonemu w akcie stanu cywilnego odpowiadają zgodnie z nim, od wielu lat istniejące stosunki rodzinne, a poza przesłankami natury biologicznej brak innych przyczyn o charakterze niemajątkowym, które by mogły przemawiać za potrzebą zmiany stanu cywilnego (Haak 2009, 29).

Podobnie w uchwale z dnia 9 czerwca 1976 r. (III CZP 46/75, OSNCP $1976 \mathrm{nr}$ 9, poz. 184; por. post. SN z dnia 3 września 1997 r., III KKO 5/97, OSNAP $1998 \mathrm{nr}$ 14, poz. 441), odnoszącej się do znaczenia prawdy obiektywnej w sprawach o ustalenie pochodzenia dziecka, Sąd Najwyższy stwierdził, że prawnomaterialne znaczenie prawdy obiektywnej w sprawach o ustalenie lub obalenie 
ojcostwa oznacza przede wszystkim, że powództwo o ustalenie lub zaprzeczenie pochodzenia dziecka nie może być oddalone na tej podstawie, że zawarte w nim żądanie stanowi realizację prawa podmiotowego sprzeczną z zasadami współżycia społecznego (art. 5 k.c.), a ustalenie prawidłowego składu rodziny leży przede wszystkim w interesie społecznym. „Zasady współżycia społecznego mogą stanowić podstawę oddalenia takiego powództwa tylko zupełnie wyjątkowo i w zasadzie tylko w sprawach o zaprzeczenie macierzyństwa" (Haak 2009, 29).

Przedstawicie doktryny, odnosząc się do kwestii dotyczącej kryterium rozstrzygania w sprawach o ustalenie lub zaprzeczenie macierzyństwa, wyrażają różne poglądy. Między innymi podkreśla się samą istotę zasad współżycia społecznego jako instrumentu służącego zwiększeniu elastyczności prawa, który powinien nie tylko szanować istniejący układ stosunków społecznych, ale również cechy określonego stanu faktycznego, do którego zastosowanie znajduje abstrakcyjna norma prawna. Sąd powinien wskazać, jakie dobro uważa za wymagające ochrony poprzez zastosowanie klauzuli zasad współżycia społecznego (Haak 2009, 85).

\section{PODSUMOWANIE}

Prawo dziecka do poznania swego pochodzenia jest tematem na tyle obszernym, że przedstawiony powyżej zakres problematyczny nie wyczerpuje w całości materii z nim związanej, chociażby ze względu na konieczność analizy zagadnień dotyczących badań biologicznych stosowanych w postępowaniach z zakresu ustalenia pochodzenia dziecka, na coraz częściej występujące w obrocie prawnym umowy o macierzyństwo zastępcze, kwestie przysposobienia czy tzw. okien życia.

Należy podkreślić, że ewolucja ustawodawstwa światowego doprowadziła do niezwykle ważnej zmiany światopoglądowej, w której dziecko z przedmiotu stało się podmiotem prawa $\mathrm{i}$ to podmiotem o nieprzeciętnie ważnej pozycji w całym systemie, który to podmiot wymaga szczególnej opieki, troski i zainteresowania nie tylko ze strony rodziny i osób najbliższych, ale również władz państwowych, samorządowych, czy samego ustawodawcy. Konwencja o Prawach Dziecka z 1989 r. dodatkowo umocniła pozycję dziecka w świecie dorosłych, przyznając mu prawa, które może samodzielnie wykonywać, w szczególności prawo do znajomości własnego pochodzenia.

Rozwój nauki postawił ludzkość nie tylko przed nowymi wyzwaniami, ale również doprowadził do konfrontacji teorii z praktyką, w której nie zawsze pochodzenie dziecka jest jasne i klarowne. Współczesne społeczeństwo stoi przed dylematami związanymi nie tylko z etyczną dopuszczalnością zabiegów medycznie wspomaganego ludzkiego rozrodu, ale również dotyczącymi pochodzenia dziecka od określonej kobiety, którego genetyczną matką nie zawsze jest ta, która je urodziła. Podobnie rzecz ma się w przypadku ustalenia pochodzenia dziecka ze strony ojca. Pojawiające się w świecie banki komórek rozrodczych, a co za tym idzie 
postulat zachowania bezwzględnej anonimowości ich dawców skłania do refleksji na temat pełnej realizacji zagwarantowanych dziecku praw.

Dokonując syntetycznej analizy poruszonych problemów, należy stwierdzić, iż po raz kolejny rzeczywistość i rozwój ludzkości doprowadziły do sytuacji, w której ustawodawca pozostał o krok w tyle, nie nadążając za zbyt szybkim przebiegiem wydarzeń w świecie nauki. Brak kompleksowej regulacji dotyczącej zabiegów medycznie wspomaganej ludzkiej prokreacji niewątpliwie nie wynika z braku zainteresowania ze strony ustawodawcy, ale z rozległych dylematów natury etycznej, moralnej czy obyczajowej. Problematyka tzw. macierzyństwa zastępczego wymaga uregulowania prawnego, gdyż uznanie, za kodeksową regulacją, że „matką dziecka jest kobieta, która je urodziła” coraz częściej nie znajduje potwierdzenia w biologicznym lub genetycznym pochodzeniu dziecka od określonej kobiety, czy nawet określonych rodziców. Pojawia się konieczność odpowiedzi na pytanie: co jest bardziej istotne - dobro i anonimowość dawców komórek rozrodczych, czy też prawda i postępowanie zgodne z ideą dobra dziecka w szczególności, jeżeli chodzi o jego przyszłość i zdrowie, które nierzadko znajomość prawdziwego pochodzenia może uratować.

Reasumując, należy stwierdzić, że dziecko jest pełnowartościowym podmiotem prawa usytuowanym na równi z człowiekiem dorosłym, że przysługują mu określone, nieraz szczególne prawa. Prawo dziecka do informacji o swym pochodzeniu we współczesnym świecie coraz częściej zyskuje na wartości, staje się prawem na tyle istotnym, że jego pominięcie, nierespektowanie czy utrudnianie jego realizacji byłoby postępowaniem wysoce nieodpowiednim.

\section{BIBLIOGRAFIA}

Andrzejewski, Marek. 2011. Prawo rodzinne i opiekuńcze. Wyd. 4. Warszawa: Wydawnictwo C.H. Beck.

Czyż, Elżbieta, Joanna Szymańczak. 1993. „Prawa dziecka w rodzinie”. W Wokół Praw Dziecka. Cz. 1. Helsińska Fundacja Praw Człowieka: 3-15. http://beta.hfhr.pl/wp-content/ uploads/2015/10/HFPC_wokol_praw_dziecka.pdf [dostęp 1.08.2018].

Działyńska, Małgorzata. 1993. „Macierzyństwo zastępcze”. Studia Prawnicze 1 (115): 87-97.

Działyńska, Małgorzata. 1996. „Problematyka prawna macierzyństwa zastępczego”. W Wspomagana prokreacja ludzka. Zagadnienia legislacyjne. Red. Tadeusz Smyczyński. 120-135. Poznań: Nakom.

Działyńska, Małgorzata. 1999. „Pochodzenie dziecka od rodziców”. W Konwencja o prawach dziecka. Analiza i wyktadnia. Red. Tadeusz Smyczyński. 135-147. Poznań: Ars Boni et Aequi.

Fras, Mariusz, Dominik Abłażewicz. 2008. „Reżim prawny macierzyństwa zastępczego na tle porównawczym". Problemy Współczesnego Prawa Międzynarodowego, Europejskiego i Porównawczego 6: 31-68.

Gołowkin-Hudała, Magdalena. 2007. „Problematyka ustalania macierzyństwa. Uwagi de lege lata i de lege ferenda". W Z zagadnień prawa rodzinnego i rejestracji stanu cywilnego. Red. Henryk Cioch, Piotr Kasprzyk. 77-92. Lublin: Katolicki Uniwersytet Lubelski Jana Pawła II, Lubelska Szkoła Biznesu. 
Haak, Henryk. 2009. Kodeks rodzinny i opiekuńczy - komentarz do art. 617-91. Toruń: Towarzystwo Naukowe Organizacji i Kierownictwa Dom Organizatora.

Haberko, Joanna, Rafał Kocyłowski. 2006. „Szczególna postać tajemnicy lekarskiej w przypadku technik wspomaganego medycznie rozrodu". Prawo i Medycyna 2: 18-32.

Holocher, Justyna, Marta Soniewicka. 2009. „Analiza prawna umowy o zastępcze macierzyństwo”. Prawo i Medycyna 3: 43-60.

Ignatowicz, Jerzy, Mirosław Nazar. 2005. Prawo rodzinne. Warszawa: Wolters Kluwer.

Jaros, Paweł. 2003. „Konstytucyjne podstawy ochrony praw dziecka”. W Polska dla dzieci, ogólnopolski szczyt w sprawach dzieci. Warszawa 23-24 maja 2003. Materiaty $i$ dokumenty. Red. Mirosław Kaczmarek, Paweł Kierenko. 35-39. Warszawa: Rzecznik Praw Dziecka.

Kosek, Mirosław. 2011. „Pochodzenie dziecka”. W Nowelizacja prawa rodzinnego na podstawie ustaw z 6 listopada 2008 r. i 10 czerwca 2010 r. Analiza, wykładnia, komentarz. Red. Wanda Stojanowska. 97-195. Warszawa: LexisNexis.

Kramska, Magdalena. 2010. „Problematyka prawna zastępczego macierzyństwa - regulacje prawnomiędzynarodowe i krajowe”. Prawo i Medycyna. http://www.prawoimedycyna.pl/index.php?st $\mathrm{r}=$ artykul\&id=688\&PHPSESSID=74177a443c2491416ddc85368946d1dd [dostęp 1.06.2018].

Nesterowicz, Mirosław. 2006. „Prokreacja medycznie wspomagana i inżynieria genetyczna - konieczność regulacji prawnych". Prawo i Medycyna 2. http://www.prawoimedycyna.pl/index. php?str=artykul\&id=133 [dostęp 28.06.2018].

Nesterowicz, Mirosław. 2007. Prawo medyczne. Toruń: Towarzystwo Naukowe Organizacji I.

Rejman, Genowefa. 1996. „Tajemnica lekarska”. Studia Iuridica 31: 147-188.

Siedlecka, Ewa. 2009. „Brzuch do wynajęcia przed sądem”. Wyborcza.pl. http://wyborcza. pl/1,75398,6914939,Brzuch_do_wynajecia_przed_sadem.html [dostęp 28.06.2018].

Silva-Ruiz, Pedro F. 1991. „Macierzyństwo zastępcze - przegląd prawnoporównawczy”. Ruch Prawniczy, Ekonomiczny i Społeczny 53 (4): 123-132.

Smyczyński, Tadeusz. 1999. „Pojęcie dziecka i jego podmiotowość”. W Konwencja o Prawach Dziecka. Analiza i wykładnia. Red. Tadeusz Smyczyński. 39-47. Poznań: Ars Boni et Aequi.

Smyczyński, Tadeusz. 2009. Prawo rodzinne i opiekuńcze. Wyd. 5 uzup. Warszawa: Wydawnictwo C.H. Beck.

Soniewicka, Marta. 2009. „Dylematy zastępczego macierzyństwa. Debata: Jak uregulować kwestię macierzyństwa zastępczego? 16.11-23.11.2009”. http://www.ptb.org.pl/pdf/soniewicka macierzynstwo_1.pdf [dostęp 10.07.2018].

Stanowisko Polskiego Towarzystwa Ginekologicznego dotyczące technik wspomaganego rozrodu w leczeniu niepłodności z 1995 r. http://www.libramedcom.pl/wpg/Numery_archiwalne/05/03.html [dostęp 25.06.2018].

Stecki, Leopold, Jan Winiarz, Janusz Gajda. 1990. „Prawo dziecka do poznania swego pochodzenia genetycznego (dwugłos)”. Państwo i Prawo 10: 64-79.

Stojanowska, Wanda, Mirosław Kosek. 2011. „Pochodzenie dziecka”. W Nowelizacja prawa rodzinnego na podstawie ustaw z 6 listopada 2008 r. i 10 czerwca 2010 r. Analiza, wyktadnia, komentarz. Red. Wanda Stojanowska. 135-144. Warszawa: LexisNexis.

Wałachowska, Monika. 2003. „Macierzyństwo zastępcze w systemie common law”. Państwo i Prawo 8: 97-107.

Wiśniewski, Leszek. 1999. „Geneza Konwencji o Prawach Dziecka i stosunek jej norm do innych aktów prawa międzynarodowego". W Konwencja o Prawach Dziecka. Analiza i wyktadnia. Red. Tadeusz Stojanowski. 11-18. Poznań: Ars Boni et Aequi.

Zielonacki, Andrzej. 1993. „Prawo do znajomości własnego pochodzenia”. Studia Prawnicze 1 (115): 99-109.

Żukowski, Łukasz. 2013. „Problemy prawne i etyczne umów o macierzyństwo zastępcze - uwagi na tle rozwiązań przyjętych w Izraelu”. W Wspótczesne koncepcje ochrony wolności i praw 
Czy dziecku przysługuje prawo do ustalenia pochodzenia genetycznego ze strony matki? 31

podstawowych. Red. Andrzej Bator, Mariusz Jabłoński, Marek Maciejewski, Krzysztof Wójtowicz. 309-328. Wrocław: Prawnicza i Ekonomiczna Biblioteka Cyfrowa.

\section{Akty prawne i dokumenty}

Deklaracja Praw Człowieka przyjęta przez Zgromadzenie Ogólne Organizacji Narodów Zjednoczonych dnia 10 grudnia $1948 \mathrm{r}$.

Deklaracja Praw Dziecka uchwalona przez Zgromadzenie Ogólne ONZ w dniu 20 listopada 1959 r. http://libr.sejm.gov.pl/tek01/txt/onz/1959.html [dostęp 6.08.2018].

Konwencja o Ochronie Praw Człowieka i Podstawowych Wolności sporządzona w Rzymie dnia 4 listopada 1950 r., zmieniona następnie Protokołami nr 3, 5 i 8 oraz uzupełniona Protokołem nr 2 (Dz.U. z 1993 r. Nr 61, poz. 284).

Konwencja o prawach dziecka, przyjęta przez Zgromadzenie Ogólne Narodów Zjednoczonych dnia 20 listopada 1989 r. (Dz.U. z 1991 r. Nr 120, poz. 526).

Przyrzeczenie Lekarskie i Kodeks Etyki Lekarskiej z dnia 2 stycznia 2004 r. (wraz ze zmianami uchwalonymi w dniu 20.09.2003 r. przez Nadzwyczajny VII Krajowy Zjazd Lekarzy). http:// www.bibl.amwaw.edu.pl/kodeks_etyki_2004.htm [dostęp 6.08.2018].

Szwedzka ustawa o inseminacji z 1984 r. - Lag om insemination „Svensk författningssamling” (SFS) 1984: 1140. http://www.riksdagen.se/sv/dokument-lagar/dokument/svensk-forfattningssamling/ lag-19841140-om-insemination_sfs-1984-1140 [dostęp 8.08.2018].

Ustawa z dnia 25 lutego 1964 r. - Kodeks rodzinny i opiekuńczy (Dz.U. z 2017 r., poz. 682).

Ustawa z dnia 17 listopada 1964 r. - Kodeks postępowania cywilnego (Dz.U. z 2018 r., poz. 1360).

Ustawa z dnia 29 września 1986 r. - Prawo o aktach stanu cywilnego (tekst. jedn. Dz.U. z 2016 r., poz. 2064).

Ustawa z dnia 5 grudnia 1996 r. o zawodach lekarza i lekarza dentysty (Dz.U. z 2018 r., poz. 617).

Ustawa z dnia 6 listopada 2008 r. o zmianie ustawy Kodeks rodzinny i opiekuńczy oraz o zmianie innych ustaw (Dz.U. z 2008 r. Nr 220, poz. 1431).

\section{Orzecznictwo}

Postanowienie SN z dnia 3 września 1997 r., III KKO 5/97, OSNAP 1998, nr 14, poz. 441.

Uchwała Pełnego Składu Izby Cywilnej SN z dnia 9 czerwca 1976 r., III CZP 46/75, OSNCP 1976, nr 9, poz. 184.

Uchwała składu siedmiu sędziów SN z dnia 7 czerwca 1971 r., III CZP 87/70, OSNCP 1972, nr 3, poz. 42.

\section{Magdalena Sobas}

\section{ABOUT THE CHILD'S RIGHT TO ESTABLISH ITS ORIGINS ON THE MOTHER'S PART}

\footnotetext{
Abstract. This text is about the child's right to determine its genetic origin in the field of establishing motherhood, also in relation to the problem of medically assisted procreation techniques and the so-called 'surrogate motherhood'. Undertaking this subject is an answer to faster-growing science and medicine. It is also an attempt to compare legal provisions with the views of representatives of the doctrine as well as everyday life in relation to the right to determine origins.

Keywords: right of the child to the information about its origin, child, motherhood, surrogate motherhood, techniques of medically assisted procreation.
} 